\title{
Toluene Alters Mu-Opioid Receptor Expression in the Rat Brainstem
}

\author{
Gonzalo SARACIBAR, Maria Luisa HERNANDEZ, Enrique ECHEVARRIA*, \\ Ismael BARBERO, Arantza GUTIERREZ and Oscar CASIS
}

Department of Physiology, School of Pharmacy, University of the Basque Country, P.O. Box 450, Vitoria, Spain

Received September 11, 2000 and accepted February 13, 2001

\begin{abstract}
Toluene is an ototoxic organic solvent widely used in industry and could be a cause of sleep apnea. Acute toluene administration in rats induces an increase in the number of neural cells immunostained for mu-opioid receptors in several brainstem nuclei, such as the inferior colliculus, dorsal and lateral periaqueductal gray and dorsal raphe, without changes in the superior colliculus and the interpeduncular and lateral reticular nuclei. These data suggest that mu-opioid receptors could be involved in toluene-induced neurotoxic effects on the physiological regulation of breathing during sleep, and auditive function.
\end{abstract}

Key words: Toluene, Mu-opioid receptors, Rat brain

\section{Introduction}

Glue sniffing ${ }^{1)}$ and occupational exposure to toluene ${ }^{2)}$ can generate ototoxicity ${ }^{3,4}$ and neuropathological changes ${ }^{5}$, such as respiratory depression ${ }^{6}$ and sleep apnea ${ }^{7}$. Toluene is detected in all brain areas after administration, with the highest concentrations in the brainstem ${ }^{8}$.

$\mathrm{Mu}$-opioid receptors are widely distributed throughout the central nervous system, including several brainstem regions, such as the dorsal raphe, involved in physiological regulation of sleep ${ }^{9)}$, the inferior and superior colliculus, that play a role in sensory integration, the periaqueductal gray lateral and dorsal, that exert a modulatory action on the basic brainstem respiratory rythm ${ }^{10}$, the lateral reticular nucleus and the interpeduncular nucleus ${ }^{11-13)}$.

It has been recently shown that chronic toluene exposure alters enkephalin immunostaining in the rat brainstem ${ }^{14)}$. However, little is known concerning the effects of toluene exposure on mu-opioid receptors. This being the case, we focused on analyzing regional mu-opioid receptor immunostaining in the rat brainstem.

*To whom correspondence should be addressed.

\section{Materials and Methods}

The experimental animals were carefully handled and all experiments were carried out in accordance with the law, avoiding animal suffering. Toluene with purity of $99 \%$ (Analytical reagent grade, Quimon Chem. Co., Spain) was used. Toluene was diluted with olive oil at a concentration of $1 \mathrm{ml} / \mathrm{ml}$ and administered intraperitoneally to the experimental group $(\mathrm{n}=6)$ at a dose of $1.3 \mathrm{ml} / \mathrm{kg} /$ day for 5 consecutive days. The selected dose was $1 / 2$ of the $\mathrm{LD}_{50}$ per day. This dose and this kind of administration have been employed to carry out studies on the adverse effects of organic solvents ${ }^{15)}$. The $\mathrm{LD}_{50}$ in rats has been found in our laboratory to be $2.61 \pm 0.41 \mathrm{ml} / \mathrm{kg} / \mathrm{day}$, calculated by the Bliss method. The control group $(\mathrm{n}=6)$ was given $0.9 \% \mathrm{NaCl}$ solution in the same volume and duration as the experimental group. Two hours after the last treatment, the animals were anaesthetized with Equithensin $(2 \mathrm{ml} / \mathrm{kg})$, an alcoholic solution of nembutal and chloral hydrate (Sigma-Aldrich Química S. A.), intraperitoneally and perfused transcardially under deep anaesthesia with saline plus $50 \mathrm{mM}$ phosphate buffer, $\mathrm{pH}$ 7.4, followed by $4 \%$ paraformaldehyde (Sigma-Aldrich Química S. A.). The brains were removed, cut into smaller pieces and then immersed in the same fixative medium overnight. They were stored for 2 days in $0.1 \mathrm{M}$ phosphate buffer containing 
$30 \%$ sucrose at $4^{\circ} \mathrm{C}$. 60 micrometer sections were cut using a cryostatic microtome (Cryocut 3.000, Leica España, Barcelona, Spain) with an stereotaxic atlas guide and immunostained for mu-opioid receptor with polyclonal antisera raised in rabbits. The antigens were detected by the avidinperoxidase technique, using 3, 3'-diaminobenzidine as chromogen (Sigma-Aldrich Química S. A.). Following reduction of endogenous peroxidases with $1 \%$ hydrogen peroxide (Sigma-Aldrich Química S. A.) and blocking of nonspecific background staining with 5\% normal goat serum (NGS) (Sigma-Aldrich Química S. A.), the sections were incubated with the following immunoreagents: 1-primary antiserum: rabbit anti mu-opioid receptor (Chemicon International Inc., Temecula, CA, USA), a commercially obtained polyclonal antibody raised in rabbits and directed against mu-opioid receptor 3rd extracellular loop peptide (dilution 1:1.000); 2-goat anti rabbit immunoglobulin: goat antirabbit biotinilated (Chemicon International Inc.), dilution 1:200; 3-avidin-peroxidase complex: strept ABC complex HRP (Dako A/S, Glostrup, Denmark), dilution 1:300; 4-chromogen: 3, 3'-diaminobenzidine (Sigma-Aldrich Química S. A.), 0.3 $\mathrm{mg} / \mathrm{ml}$ in $0.2 \mathrm{M}$ Tris $\mathrm{HCl}$ buffer containing $0.03 \%$ hydrogen peroxide. Each step was followed by an appropiate wash per triplicate in phosphate buffer saline and $0.3 \%$ Triton X-100 (Sigma-Aldrich Química S. A.) was used. Sections were carefully extended, dehydrated and mounted (DPX mountant for histology, Fluka Chemie AG, Buchs, Switzerland), and examined with an Olympus BX50F optic microscope (Olympus Optical Co. Ltd., Japan). A Leica image analysis system (Quantimet 500 MC, Leica España S. A., Barcelona, Spain) was used to obtain digitized images from brainstem slices and to trace a target area. To valorate the density of positively stained neural cells, random counts were manually made in a particular area that was previously performed by tracing contours with a cursor. At least six random counts of positively immunostained neural cells for an particular area were made in every section analyzed, and no less than 10 sections were selected in every rat $(n=6)$ and brain region. The results obtained were referred as the number of neural cells $/ \mathrm{mm}^{2}$ positively immunostained for mu-opioid receptors, in treated animals and controls (mean \pm S.E.M.). Differences between means were calculated by the Student's T test. Statistically significant differences were considered at $\mathrm{p}<0.01$.

\section{Results}

Utilization of a specific polyclonal antibody against muopioid receptors showed the presence of abundant round cells intensely immunostained in the dorsal raphe, inferior

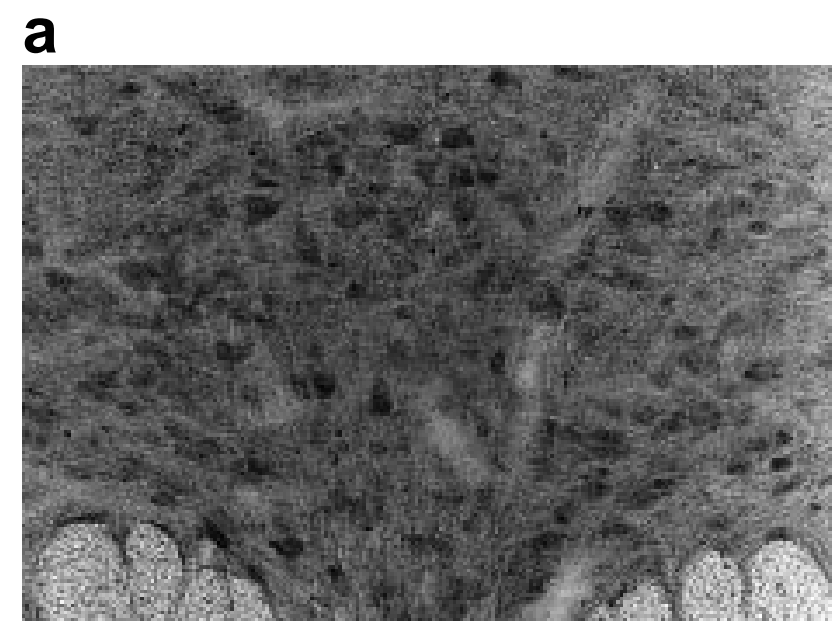

\section{b}

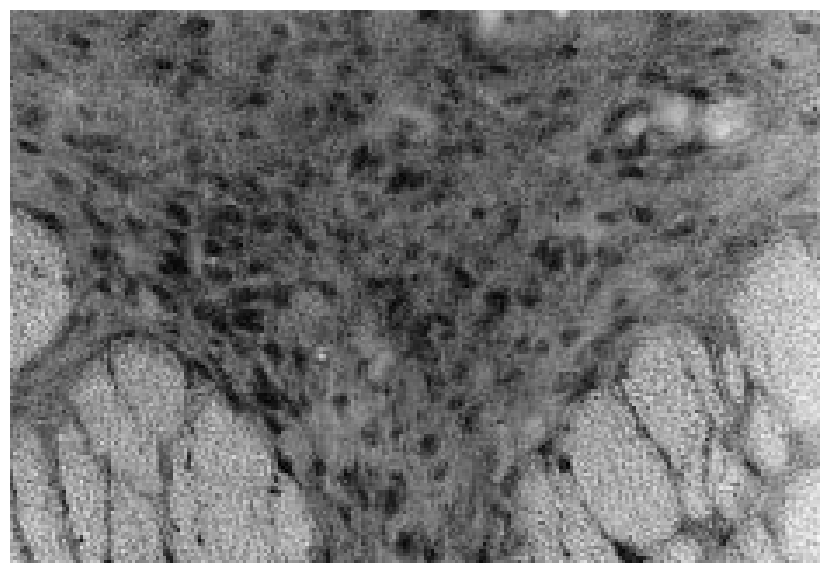

Fig. 1 Light micrographs of brainstem coronal sections immunostained for mu opioid receptors in control (1a) and toluene treated rats (1b).

Immunostained neural cells can be seen in the dorsal raphe. 16x.

and superior colliculus, periaqueductal gray lateral and dorsal, interpeduncular nucleus and lateral reticular nucleus.

An increase in the density of neural cells inmunostained for mu-opioid receptors in the periaqueductal gray dorsal and lateral, dorsal raphe (Fig. 1) and inferior colliculus, without changes in superior colliculus, interpeduncular nucleus and lateral reticular nucleus was found, with respect to controls (Fig. 2).

\section{Discussion}

Toluene is an ototoxic organic solvent that increases free intracellular calcium levels in the spiral ganglion and the outer hair cells ${ }^{16)}$. Although its action focuses preferently on cochlear middle and mid-apical turns ${ }^{17}$, electrocochleographic recording of auditory evoked 


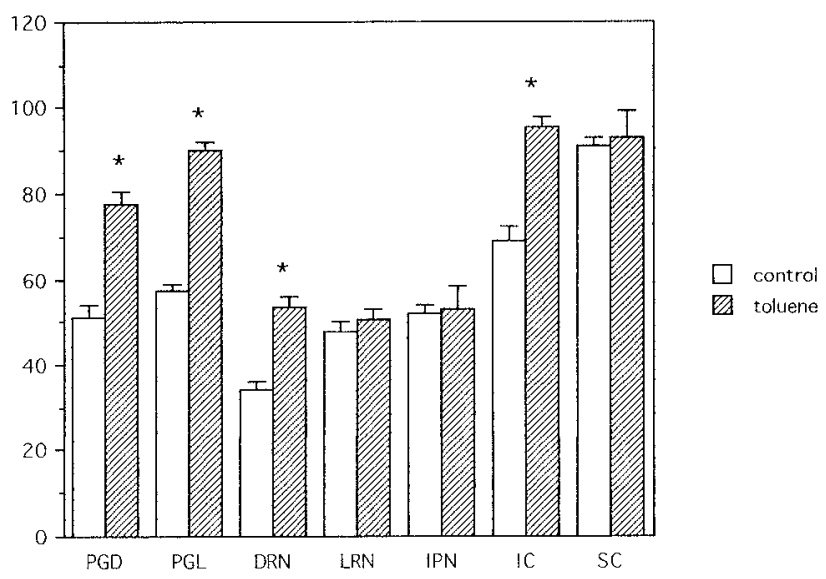

Fig. 2 Graphic representation of variations in the density of neural cells immunostained for mu-opioid receptors in the selected brain regions, expressed in cells $/ \mathrm{mm}^{2}$, in control and toluene treated rats. The key for the representation is as follows: PGD (periaqueductal gray dorsal), PGL (periaqueductal gray lateral), DR (dorsal raphe), IPN (interpeduncular nucleus), LRN (lateral reticular nucleus), IC (inferior colliculus), SC (superior colliculus).

potentials from the round window show a hearing deficit also in the mid-low frequency region in rats, after toluene exposure ${ }^{18)}$. Thus, it has been confirmed, through recording of inferior colliculus auditory-evoked potentials, that chronic exposure to toluene alters auditive function ${ }^{19)}$.

Although it is well known that cochlear damage by acoustic overstimulation impairs the sensitivity of auditory nerve fibers and reduces the neural output of the cochlea, electrophysiological studies have shown an increased activity in the inferior colliculus after experimental induction of cochlear lesions, suggesting a involvement of this region in the adaptative changes of central auditory pathway function that account to compensate the reduced neural activity generated by the cochlea ${ }^{20)}$. Accordingly, in the results here reported, an increase in mu-opioid receptor immunostaining in the inferior colliculus has been observed. This is in agreement with previous reports suggesting a connection between opioid receptors and auditory neural function ${ }^{21)}$. Thus, neurons double-labeled for GABA(A) receptors and opioid receptors (mu and kappa) have been described in the inferior colliculus $^{22}$, suggesting that both GABAergic and opioidergic systems could be involved in the functional regulation of central auditory pathway. Due to the physiological role of the inferior colliculus in auditive signal proccessing, mu-opioid receptors could be involved in toluene-induced neurotoxic effects on auditive function, as well as in the adaptative response of the central auditive pathway against cochlear damage.

It is well known that opioids decrease respiration ${ }^{23,29)}$ through a suppression of brainstem baseline inspiratory neuronal activity ${ }^{24)}$, and mu-opioid receptors are involved in respiratory depression after opioid overdose ${ }^{25)}$. Thus, it has been described that periaqueductal gray and other suprapontine regions exert a modulatory action on the basic brainstem respiratory rythm ${ }^{10}$. In the results here reported, a lack of changes in mu-opioid receptor expression in the lateral reticular nucleus, involved in the regulation of breathing, has been observed. However, the number of neural cells immunostained for mu-opioid receptors in the periaqueductal gray dorsal and lateral was increased after toluene administration. These results suggest that mu-opioid receptors in the periaqueductal gray could be involved in the neurotoxic mechanism of toluene-induced respiratory depression.

Occupational toluene exposure can generate sleep apnea ${ }^{7,30)}$. Dorsal raphe is involved in the physiological regulation of sleep") and a inhibitory role on REM sleep has been suggested for serotonergic neurons in this region ${ }^{26)}$. Thus, alterations in the regulation of respiratory motor output in response to increased lends in non-REM sleep have been described ${ }^{27)}$ and mu-opioid receptors in the dorsal raphe are involved in opioid-induced REM sleep inhibition, through activation of $\mathrm{G}$ proteins $\mathrm{s}^{28)}$. Accordingly, in the results here reported, an increase in mu-opioid receptor immunostaining in the dorsal raphe has been observed after toluene administration in rats. These results suggest that mu-opioid receptors could be involved in the neurotoxic mechanism of toluene-induced sleep apnea.

Further studies focusing on description of possible alterations in mu-opioid receptor function after toluene exposure are needed to clarify the role of the brainstem opioid system in organic solvent-induced impairments in the regulation of sleep, breathing and auditive function.

\section{Acknowledgments}

This work has been partially supported by a FIS grant (98/0028-01), a GV grant (PI97/37) and a UPV/EHU grant (081.123-EA094/99). We would like to thank J.M. Rodríguez Robledo for his technical assistance.

\section{References}

1) Meadows R, Verghese A (1996) Medical complications of glue sniffing. Southern Med J 89, 455-62.

2) Hageman G, Van der Hoek J, Van Hout M, Van der Laan G, Steur EJ, De Bruin W, Herholz K (1999) Parkinsonism, pyramidal signs, polyneuropathy, and cognitive decline after long-term occupational solvent 
exposure. J Neurol 246, 198-206.

3) Campo P, Loquet G, Blachere V, Roure M (1999) Toluene and styrene intoxication route in the rat cochlea. Neurotoxicol Teratol 21, 427-34.

4) Morata TC, Nylen P, Johnson AC, Dunn DE (1995) Auditory and vestibular functions after single or combined exposure to toluene: A review. Arch Toxicol 69, 431-43.

5) Yamanouchi N, Okada SI, Kodama K, Sato T (1998) Central nervous system impairment caused by chronic solvent abuse. A review of Japanese studies on the clinical and neuroimaging aspects. Addiction Biol 3, 15-27.

6) Flanagan RJ, Ruprah M, Meredith TJ, Ramsey JD (1990) An introduction to the clinical toxicology of volatile substances. Drug Safe 5, 359-83.

7) Laire G, Viaene MK, Veulemans H, Masschelein R, Nemeri B (1997) Nocturnal oxygen desaturation, as assessed by home oximetry, in long-term solventexposed workers. Am J Ind Med 32, 656-64.

8) Gospe SMJr, Calaban MJ (1988) Central nervous system distribution of inhaled toluene. Fund Appl Toxicol 11, 540-5.

9) McCarley RW, Greene RW, Rainnie D, Portas CM (1995) Brainstem neuromodulation and REM sleep. Seminars Neurosci 7, 341-54.

10) Horn EM, Waldrop TG (1998) Suprapontine control of respiration. Resp Physiol 114, 201-11.

11) Ding YQ, Kaneko T, Nomura S, Mizuno, N (1996) Immunohistochemical localization of mu-opioid receptors in the central nervous system of the rat. J Comp Neurol 367, 375-402.

12) Hiller JM, Zhang Y, Bing T, Gioannini TL, Stone EA, Simon EJ (1994) Immunohistochemical localization of mu-opioid receptors in rat brain using antibodies generated against a peptide sequence present in a purified mu-opioid binding protein. Neuroscience 62, 829-41.

13) Kaneko T, Minami M, Satoh M, Mizuno, N (1995) Immunocytochemical localization of mu-opioid receptor in the rat caudatus-putamen. Neurosci Lett 184, 149-52.

14) Gandarias JM, Echevarría E, Serrano R, Silió M, Casis L (1998) Toluene alters brainstem enkephalinergic system in rats. Ind Health 36, 247-51.

15) Pappolla M, Penton R, Weiss HS, Miller CHJr, Sahenk Z, Autilio-Gambetti L, Gambetti P (1987) Carbon disulfide axonopathy. Another experimental model characterized by acceleration of neurofilament transport and distinct changes of axonal size. Brain Res 424, 272 80.
16) Liu Y, Fechter LD (1997) Toluene disrupts outer hair cell morphometry and intracellular calcium homeostasis in cochlear cells of guinea pigs. Toxicol Appl Pharmacol 142, 270-7.

17) Campo P, Lataye R, Cossec B, Placidi V (1997) Toluene-induced hearing loss: A mid-frequency location of the cochlear lesions. Neurotoxicol Teratol 19, 12940.

18) Lataye R, Campo P, Loquet G (1999) Toluene ototoxicity in rats: Asssessment of the frequency of hearing deficit by electrocochleography. Neurotoxicol Teratol 21, 267-76.

19) Campo P, Lataye R, Cossec B, Villette V, Roure M, Barthelemy C (1998) Combined effects of simultaneous exposure to toluene and ethanol on auditory function in rats. Neurotoxicol Teratol 20, 321-32.

20) Salvi RJ, Wang J, Ding D (2000) Auditory plasticity and hyperactivity following cochlear damage. Hear Res 147, 261-74.

21) Sahley TL, Musiek FE, Nodar RH (1996) Naloxone blockade of pentazocine-induced changes in auditory function. Ear Hear. 17, 341-53.

22) Kalyuzhny AE, Dooyema J, Wessendorf MW (2000) Opioid- and GABA(A)-receptors are co-expressed by neurons in rat brain. Neuroreport 11, 2625-8.

23) Takita K, Herlenius EAP, Lindahl SGE, Yamamoto $Y$ (1997) Actions of opioids on respiratory activity via activation of brainstem mu, delta and kappa receptors; an in vitro study. Brain Res 778, 233-41.

24) Bonham AC (1995) Neurotransmitters in the CNS control of breathing. Resp Physiol 101, 219-30.

25) White JM, Irvine RJ (1999) Mechanism of fatal opioid overdose. Addiction 94, 961-72.

26) Portas CM, Bjorvatn B, Ursin R (2000) Serotonin and the sleep/wake cycle: special emphasis microdialysis studies. Prog Neurobiol 60, 13-35.

27) Dempsey JA, Smith CA, Harms CA, Chow CM, Saupe KW (1996) Sleep-induced breathing instability. State of the art review. Sleep 19, 236-47.

28) Capece ML, Baghdoyan HA, Lydic R (1998) Opioids activate $\mathrm{G}$ proteins in REM sleep-related brainstem nuclei of rat. Neuroreport 9, 3025-8.

29) Bianchi AL, Denavit-Saubié M, Champagnat J (1995) Central control of breathing in mammals: neuronal circuitry, membrane properties, and neurotransmitters. Physiol Rev 75, 1-45.

30) Vgontzas AN, Kales A (1999) Sleep and its disorders. Ann Rev Med 50, 387-400. 